\title{
O PATRIARCADO MODERNO E O REFORÇO AOS ESTEREÓTIPOS DE GÊNERO: ANÁLISE À LUZ DO PROGRAMA BOLSA FAMÍLIA NO MUNICÍPIO DE PORTO SEGURO
}

\author{
AUTOR:TRACY CRISTIANE SOARES DOS SANTOS \\ CO-AUTOR/ORIENTADOR: CRISTINA GROBERIO PAZO
}

Resumo: O capitalismo tardio e o patriarcado se interpenetram no modus operandi da reprodução das situações de desigualdades entre homens e mulheres no Brasil atual. A responsabilização social pela conservação da família recai prioritariamente sobre as mulheres em nosso país, principalmente das famílias com menor poder aquisitivo. Uma das soluções apresentadas, a fim de apaziguar os problemas da miserabilidade da maioria das famílias, foi a criação do Programa Bolsa Família, logo o objetivo deste Projeto é esclarecer se o programa Bolsa Família reproduz ou não os estereótipos de gênero com a hipótese de que a mulher é a principal beneficiária do bolsa família, reforçando os arquétipos já estabelecidos para o sexo feminino e a associação da mulher com a maternidade e serviços domésticos. O presente trabalho pretende analisar através das teorias feministas os processos em torno dos estereótipos de gênero do Programa Bolsa Família para as mulheres assistidas no município de Porto Seguro e regiões vizinhas.

Palavras-chave: Bolsa Família, Gênero, Pandemia, Autonomia. 